\title{
PREFIX AND SUFFIX ANALYSIS IN RELATION WITH STUDENTS ENGLISH ABILITY
}

\author{
Ro'aini' ${ }^{1}$, Fithrah Auliya Ansar ${ }^{2}$ \\ UIN Raden Intan Lampung \\ Email: tabassamaini7@gmail.com
}

\begin{abstract}
This thesis was about the students' ability in using prefix and suffix. The purpose of this research was to know how far is the students' abilities in using prefix and suffix. This research was conducted at the first semester of twelfth grade of SMK BLK Bandar Lampung in 2018/2019 academic year.

The type of this research was descriptive quantitative research. The subject of this research was 205 students of twelfth grade in 8 classes. The data of this research was obtained by using test. The researcher analyzed the data by giving score the students' test, determining the students' ability classification, and calculating the frequency's percentage and the average of students' score, so the students' ability in using prefix and suffix could be known.

Based on the result of the research, the percentage of students' ability in using prefix and suffix of excellent level students' score was $3.90 \%$ or 8 students, good level students' score was $17.56 \%$ or 36 students, fair level students' score was $13.17 \%$ or 27 students, low level students' score was $11.22 \%$ or 23 students, and failed students' score was $54.15 \%$ or 111 students. The majority of correct prefix was inter- by 172 items, and the majority of correct suffixes were -ment and-ion by 139 items. Moreover, the majority of correct part of speech used in test was verb. In conclusion, the average of students' ability in using prefix and suffix at the first semester of twelfth grade of SMK BLK Bandar Lampung in 2018/2019 academic year was 46.67. So, it was categorized into low level.
\end{abstract}

Key words: parts of speech, prefix and suffix, students' ability

\section{A. INTRODUCTION}

Vocabulary is one of the most essential parts of second language acquisition and can be broadly defined as knowledge of words and word meaning (Kim, 2013). It means that vocabulary is important in daily life, because vocabulary means how much someone' mastery of language, exactly words.

Vocabulary consists of many aspects, such as word classes or parts of speech, word families, word formation, multi-word units, collocations, homonyms, polysemes, 
synonyms and antonyms, hyponyms, and etc (Thornbury, 2002). In this case, it will be discussed about word formation. Affix is one of terms in word formation. Some affixes may change part of speech, like adjective 'happy' will change to be noun 'happiness' because of one of affixes, '-ness'. An affix may attach to either side of the root or to either side of the initial segment or syllable of the lexical item (Kim, 2013). It means that a core of word or base can be added by affix, and it can be at the beginning or at the end of the word.

Studying vocabulary with affix systems or patterns would seem to be much more effective language for learners than just memorizing words (Kim, 2013). As mentioned above that vocabulary is knowledge about words and their meanings, while detail explanation about affix is in morphology. In linguistics, morphology refers to the mental system involved in word formation or to the branch of linguistics that deals with words, their internal structure, and how they are formed (Aronoff, 2011). In other words, when learners study vocabulary and morphology at once, it will be better. They can get more knowledge about forming words too than just mastery of collection of words. It means that morphology supports vocabulary, because it discusses more clearly about affixes than vocabulary. So, affix is important to be learned to improve the vocabulary mastery.

Affix is divided into two kinds, those are prefixes and suffixes. A prefix at the beginning of a word has a meaning of its own that changes the meaning of the word it is joined to (Side and Wellman, 1999). In other words, prefix attaches in front of base word and changes its meaning. Prefixes are often used to give adjectives a negative meaning. For examples, the opposite of 'comfortable' is 'uncomfortable', the opposite of 'convenient' is 'inconvenient' and the opposite of 'similar' is 'dissimilar' (McCarthy and O'Dell, 1994). Based on those prefixes, they precede adjectives and have meaning "not" to words attached. A suffix changes the meaning of the word it is joined to only by changing its part of speech; e.g., we can add -ity to the adjective national to make the noun nationality (Side and Wellman, 1999). 
Adding suffix at word may also change part of speech, not only changes meaning of word. In addition, it is kind of affixes that are located in the end of the word. So, based on the example suffix is an affix that attaches itself behind of base word.

The researcher did the interview to two English teachers of SMK BLK Bandar Lampung in Sukarame, Bandar Lampung. They told much information about the English teaching and learning process of their classes. The first teacher said that the English students' ability of her students was average. There were some students had a good ability or had a basic of English, but some others were still low yet. Whereas, the second teacher said that the students' vocabulary mastery was low. They both explained that the students were difficult to distinguish parts of speech, so they were confused to use the correct form of prefixes or suffixes (Yoharisna and Tekky, S.S, 2017-2018).

Based on preliminary research above, therefore the researcher made a thesis under the title "An Analysis of Students' Ability in Using Prefix and Suffix at the First Semester of Twelfth Grade of SMK BLK Bandar Lampung in 2018/2019 Academic Year". The reason of researcher did this research was because the researcher tried to describe how far are the students' abilities in using prefix and suffix. It was also supported by some previous researches that were conducted before this research.

The first previous research is by Roliah about "An Analysis of Students' Mastery in Derivational Vocabulary at the First Semester at the Tenth Grade of SMAN 1 Sekampung Lampung Timur in 2013/2014 Academic Year". This research was conducted at SMAN 1 Sekampung Lampung Timur, Lampung City in 2014. Based on the result of this research, the researcher found that the highest frequency the students' mastery based on derivational prefix with $52.07 \%$ and derivational suffix is $47.93 \%$. The differences between this first previous research and this research were the researcher used four main parts of speech to test the students' ability in using prefix and suffix. Those were noun, adjective, verb, and adverb. While in this 
first previous research, it was only three parts of speech (noun, adjective, and verb). The subject of the research was also different. In this previous research, the researcher used tenth grade, but in this research, the researcher used twelfth grade suitable with the current syllabus.

The second previous research is by Lastari, Suharni, and Sesmiyanti about "An Analysis of Students' Ability in using Affix at the Third Year Students of English Department of STKIP PGRI West Sumatera in Academic Year 2015/2016". This research was conducted at Padang State University, Padang City in 2015. The result of this research were $62.5 \%$ students had not thoroughly understood about affix and $37.5 \%$ of total sample had understood about affix commonly. The differences between this second previous research and this research were the purpose, subject and object of the research. This second previous research was conducted to know the students' ability of English Education Study Program in university in using derivational prefix, derivational suffix, inflectional suffix or infix. While in this research, the researcher only wanted to know the students' ability in using derivational prefix and derivational suffix at the twelfth grade of Vocational School. So, these were some differences among this research and these previous researches.

\section{B. RESEARCH METHOD}

This research was conducted to analyze the students' ability in using prefix and suffix at the first semester of twelfth grade students of SMK BLK Bandar Lampung. Furthermore, the researcher chose descriptive quantitative. Descriptive quantitative is research method that describes the characteristics of the population or phenomenon that is being studied. Descriptive quantitative research as the design of this research. The researcher used non-probability sampling, and the technique is saturated sampling or total sampling. This technique used because the researcher would take all population. The students' population was 264 students of 9 classes, and the researcher took all students as to be the objects' research. 1 class that is XII 
TKJ 1 for tryout and 8 classes those are XII TKJ 2, XII TKR 1, XII TKR 2, XII TSM 1, XII TSM 2, XII TD 1, XII TD 2, and XII MM for the test.

In conducting tryout, the researcher gave 50 items of multiple choices vocabulary test to 34 students. The researcher used Anates Pilihan Ganda V.4.0.9 Application Program to get the validity and the reliability of items test. After tryout, there are 20 valid items to be used in test and the reliability was very high or 0.86 . Then, only 205 students followed the test, and the rest 59 students did not come and/or did not want do the test.

\section{FINDINGS AND DISCUSSION}

This section discusses the findings and discussion of the research.

\section{Findings}

The result of the test in 8 classes can be seen on the tables and figure below.

Table 1. the Result of Students' Work in Each Affix

\begin{tabular}{|c|c|c|c|c|c|c|c|c|c|c|c|c|}
\hline \multirow[b]{2}{*}{ No } & \multicolumn{3}{|c|}{ Items Test } & \multicolumn{8}{|c|}{ Twelfth Grade (Class XII) } & \multirow[b]{2}{*}{$\sum$} \\
\hline & Pre & Suf & $\begin{array}{c}\text { Parts of } \\
\text { Speech }\end{array}$ & TKJ 2 & TKR 1 & TKR 2 & TSM 1 & TSM 2 & TD 1 & TD 2 & MM & \\
\hline 1 & re- & & verb & 15 & 9 & 7 & 3 & 1 & 8 & 6 & 5 & 54 \\
\hline 2 & & -or & noun & 26 & 12 & 6 & 15 & 5 & 11 & 27 & 1 & 103 \\
\hline 3 & & -ment & noun & 25 & 12 & 24 & 16 & 2 & 35 & 19 & 16 & 139 \\
\hline 4 & dis- & & verb & 33 & 18 & 14 & 9 & 3 & 39 & 15 & 10 & 137 \\
\hline 5 & & $-1 y$ & adverb & 16 & 12 & 5 & 4 & 6 & 12 & 8 & 14 & 79 \\
\hline 6 & & -ing & verb & 28 & 15 & 30 & 8 & 1 & 3 & 9 & 2 & 96 \\
\hline 7 & mis- & & verb & 12 & 12 & 15 & 2 & 8 & 6 & 11 & 11 & 81 \\
\hline 8 & fore- & & noun & 22 & 15 & 14 & 4 & 0 & 10 & 14 & 12 & 91 \\
\hline 9 & & -ism & noun & 19 & 6 & 9 & 6 & 6 & 8 & 7 & 14 & 75 \\
\hline 10 & post- & & verb & 14 & 5 & 10 & 4 & 19 & 13 & 14 & 2 & 76 \\
\hline 11 & inter- & & verb & 43 & 15 & 12 & 11 & 15 & 28 & 38 & 10 & 172 \\
\hline 12 & & -er & noun & 23 & 6 & 7 & 3 & 4 & 15 & 7 & 10 & 82 \\
\hline 13 & & $-\mathrm{al}$ & adjective & 19 & 15 & 11 & 8 & 8 & 29 & 15 & 1 & 106 \\
\hline 14 & pre- & & verb & 17 & 3 & 5 & 5 & 13 & 7 & 6 & 10 & 66 \\
\hline 15 & & -ion & noun & 19 & 15 & 13 & 4 & 12 & 37 & 18 & 11 & 139 \\
\hline 16 & & -ness & noun & 15 & 9 & 2 & 12 & 3 & 7 & 9 & 6 & 57 \\
\hline 17 & & $-\mathrm{s}$ & verb & 40 & 3 & 12 & 16 & 1 & 4 & 4 & 15 & 92 \\
\hline 18 & & -ful & adjective & 38 & 2 & 9 & 13 & 9 & 13 & 26 & 13 & 124 \\
\hline 19 & out- & & verb & 36 & 9 & 14 & 4 & 3 & 19 & 16 & 1 & 102 \\
\hline 20 & & -ed & verb & 12 & 6 & 6 & 5 & 3 & 4 & 7 & 12 & 59 \\
\hline$\sum$ & 8 & 12 & & 472 & 199 & 225 & 152 & 122 & 308 & 276 & 176 & 1930 \\
\hline
\end{tabular}




760

610

1540

From table 1, the researcher found that the majority of correct prefix was interby 172 items, and the majority of correct suffixes were -ment and -ion by 139 items. Therefore, the class that had the highest score in using prefix and suffix was XII TKJ 2 by score 2360, while the class that had the fewest score in using prefix and suffix was XII TSM 2 by score 610. Moreover, the majority of correct part of speech was verb in test, because prefix inter-attached to word "connect" that means is a transitive verb that connects to each other.

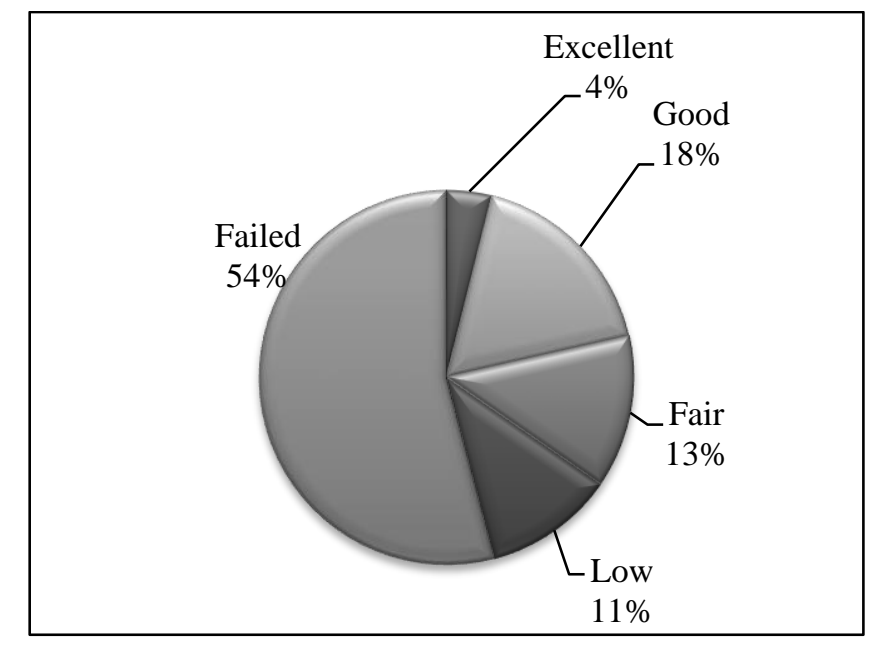

Figure 1. the Classification of Students' Ability in Using Prefix and Suffix

From figure 1, the researcher found that $3.90 \%$ or 8 students were included in excellent level, $17.56 \%$ or 36 students were included in good level, $13.17 \%$ or 27 students were included in fair level, $11.22 \%$ or 23 students were included in low level, and $54.15 \%$ or 111 students were included in failed level.

Table 2. the Average Students' Score in using Prefix and Suffix

\begin{tabular}{|c|c|c|c|c|c|}
\hline \multirow{2}{*}{ No } & \multirow{2}{*}{ Class } & \multicolumn{2}{|c|}{ The Students' Average Score } & \multirow{2}{*}{$\begin{array}{c}\text { Total of } \\
\text { Students }\end{array}$} & $\begin{array}{c}\text { The Average } \\
\text { Score }\end{array}$ \\
\cline { 3 - 4 } & Prefix & Suffix & \\
\hline
\end{tabular}




\begin{tabular}{|c|c|c|c|c|c|}
\hline 1 & XII TKJ 2 & 27.43 & 40 & 35 & 67.43 \\
\hline 2 & XII TKR 1 & 20.47 & 26.91 & 21 & 47.38 \\
\hline 3 & XII TKR 2 & 18.20 & 26.80 & 25 & 45 \\
\hline 4 & XII TSM 1 & 9.13 & 23.91 & 23 & 33.04 \\
\hline 5 & XII TSM 2 & 15.50 & 15 & 20 & 30.50 \\
\hline 6 & XII TD 1 & 19.12 & 26.17 & 34 & 45.29 \\
\hline 7 & XII TD 2 & 18.18 & 23.64 & 33 & 41.82 \\
\hline 8 & XII MM & 21.79 & 41.07 & 14 & 62.86 \\
\hline \multicolumn{2}{|l|}{ Average } & 18.73 & 27.94 & 205 & 46.67 \\
\hline
\end{tabular}

From the data above, there were 205 students at the first semester of twelfth grade of SMK BLK Bandar Lampung in 2018/2019 academic year whose the average score of test or the students' ability in using prefix and suffix was 46.67 included low level. In addition, the largest average score class was XII TKJ 2 by 67.43 . Then, the students' ability in using prefix was $47.50 \%$ and the students' ability in using suffix was $46.79 \%$.

\section{Discussion}

The researcher used multiple choices test as an instrument. The test consisted of 20 items which was divided into two material aspects, such as prefix and suffix. They were 20 derivational affixes, 8 prefixes and 12 suffixes. The prefixes were dis-, mis, inter-, out-, fore-, re-, pre-, and post-. Then, the suffixes were-er, -or, -ism, -ion, -ment, -ness, -ed, -s, -ing, -al, -ful, and -ly. The parts of speech that used were noun, verb, adjective, and adverb. The test had 4 options of answer, and it should be finished in 35-40 minutes. In reality, there were 264 students at the twelfth grade, but there were 59 students did not come on the day of test and/or they did not want to do the test. It was only 205 students who did the test, so it caused the result of the research was not really detail and complete.

Based on the result of the research, the researcher obtained that the percentage students' ability in using prefix and suffix at the first semester of the twelfth grade of SMK BLK Bandar Lampung in the academic year 2018/2019 by 205 students were: the percentage of students' ability in using prefix was $47.50 \%$ and suffix was $46.79 \%$. The percentage of excellent level was 8 students or $3.90 \%$, good level was 
36 students or $17.56 \%$, fair level was 27 students or $13.17 \%$, low level was 23 students or $11.22 \%$, and failed level was 111 students or $54.15 \%$.

From the result, it can be known that the most correct prefix was inter- by 172 items, and the most correct suffixes were -ment and -ion by 139 items. Meanwhile, 5 most incorrect affixes were re-, -ness, -ed, -ism, and post-. Moreover, re-, -ed, and post-were affixes of verb in test, but -ness, and -ism were affixes of noun in test. In addition, the most correct part of speech was verb in test. The item test was number 11 with affix inter- to word 'connect'. The meaning is a transitive verb that connects to each other.

The researcher also got the class that had the highest score in using prefix and suffix was XII TKJ 2 by score 2360. Meanwhile, the class that had the lowest score was XII TSM 2 by score 610. Moreover, the largest average score class was XII TKJ 2 by 67.43. Then, the average score at the first semester of the twelfth grade of SMK BLK Bandar Lampung in the academic year 2018/2019 in using prefix and suffix was 46.67. It meant that the students' ability in using prefix and suffix belongs to low level.

After analyzing the data, the researcher hoped that the students should learn English enthusiastically, so they can have better students' ability in vocabulary especially prefix and suffix system. They can identify all of parts of speech and many affixes in English also. By this research, the teacher can know how the students' ability in using prefix and suffix was. After knowing the result of the research, the teacher can teach the students about affix and parts of speech deeper, so that the students will understand well about vocabulary more.

Besides, the teacher can use more interesting technique or media in teaching learning English, so the students can increase their motivation. The teacher should be patient and do not be quickly to teach the students whose a low motivation. They 
must be curious to the topic of material first, so that they want to pay attention to the teacher. The review of prefix and suffix by the researcher may give positive understanding for the students before they do the test of using prefix and suffix. After doing the test, the students will understand more about prefix and suffix. They have to practice to do the exercises about adding affix, so they can master many more vocabularies than before.

The differences among this research and the first previous research were the sampling technique, the instrument form, and the result. In the first previous research, it was used purposive sampling technique and gap fill test, while in this research it was used probability sampling technique and multiple choices test. The affixes used in the first previous research were dis-, mis-, im-, in-, un, -ous, -ity, ation, -ness, -ive, -al, -ment, -ful, and -ly. Then, in this research it was used dis-, mis-, inter-, out-, fore-, re-, pre-, post-, -er, -or, -ism, -ion, -ment, -ness, -ed, -s, ing, -al, -ful, and -ly. The result of the first previous research was only about the frequency of the students' vocabulary mastery based on derivational prefix with $52.07 \%$ and derivational suffix is $47.93 \%$. Whereas, in this research the results were about the percentage of students' ability in using prefix was $47.50 \%$ and suffix was $46.79 \%$. The percentage of excellent level was 8 students or $3.90 \%$, good level was 36 students or $17.56 \%$, fair level was 27 students or $13.17 \%$, low level was 23 students or $11.22 \%$, and failed level was 111 students or $54.15 \%$. It was also resulted about the average score in using prefix and suffix was 64.67 or low level.

The differences among this research and the second previous research were the sampling technique, the research object and the result. In the first previous research, it was used random sampling technique and 12 items for derivational prefix, 17 items for derivational suffix, 16 items for inflectional suffix, and 5 items for infix. While in this research it was used probability sampling technique and 8 items for derivational prefix, and 12 items for derivational suffix. The results of the second previous research were about percentages students' score ability were $37.5 \%$ for 
good classification, $55 \%$ for fair classification and $7.5 \%$ for poor classification. The percentages of students' ability in using were $41.7 \%$ for derivational prefix, $23.5 \%$ for derivational suffix, $81.5 \%$ for inflectional suffix and $0 \%$ for infix. Whereas, in this research the results were about the percentage of students' ability in using prefix was $47.50 \%$ and suffix was $46.79 \%$. The percentage of excellent level was 8 students or $3.90 \%$, good level was 36 students or $17.56 \%$, fair level was 27 students or $13.17 \%$, low level was 23 students or $11.22 \%$, and failed level was 111 students or $54.15 \%$. It was also resulted about the average score in using prefix and suffix was 64.67 or low level.

\section{CONCLUSION AND SUGGESTION}

This section discusses the conclusion and suggestion of the research.

\section{Conclusion}

The result of the data analysis of students' ability in using prefix and suffix at the first semester of the twelfth grade students of SMK BLK Bandar Lampung in academic year 2018/2019 were:

1. The students' ability in using prefix and suffix that had excellent level were 8 students or $3.90 \%$, good level were 36 students or $17.56 \%$, fair level were 27 students or $13.17 \%$, low level were 23 students or $11.22 \%$, and failed level were 111 students or $54.15 \%$. It was failed level by the average score 64.67 of 205 students.

2. The majority of correct prefix was inter- by 172 items.

3. The majority of correct suffixes were -ment and -ion by 139 items.

4. The majority of correct part of speech was verb in test.

From the data analysis above, we can see that Students In SMK BLK is good in Affix.

\section{Suggestion}

According to the result of the research, the researcher would like to give some suggestions as follows: 


\section{For the Next Researcher}

This research was about an analysis of students' ability in using prefix and suffix at the first semester of the twelfth grade students of SMK BLK Bandar Lampung in 2018/2019 academic year. The researcher hoped this research can be used as new literature for another research about affixes with different research type, sampling technique, or instrument.

\section{For the English Teachers}

a. The English teacher should be creative in teaching prefix and suffix. For example, the teacher can apply a fun game, so that all students can involve themselves in classroom activities.

b. The English teacher may explain the affix system and parts of speech step by step clearly.

c. The English teacher should give interesting motivations and stimulates the students how important the use of prefix and suffix to increase the students' ability.

\section{For the Students}

a. The students should have a big motivation, spirit, and interest to learn English, especially about prefix and suffix.

b. The students should participate actively in classroom, such as asking and answering, discussing, and so on, especially about prefix and suffix material.

c. The students should understand the material about prefix and suffix.

d. The students have to keep practicing of the use prefix and suffix well.

\section{E. REFERENCES}

Argenis A. Zapata. (2007). Unit 1: Types of Words and Word-Formation Processes in English. Bogota: Universidad de Los Andes

Arikunto, Suharsimi. ed. Restu Damayanti. (2015). Dasar-Dasar Evaluasi Pendidikan, (2 ${ }^{\text {nd }}$ ed). Jakarta: Bumi Aksara

(2010). Prosedur Penelitian, Suatu Pendekatan Praktik (14 $4^{\text {th }}$ ed). Jakarta: Rineka Cipta 
(2013). Prosedur Penelitian, Suatu Pendekatan Praktik (15 ${ }^{\text {th }}$ ed). Jakarta: Rineka Cipta

Aronoff, Mark, Fudeman, Kirsten. (2011). What is Morphology ( ${ }^{2} \mathrm{nd}$ ed). Oxford: Blackwell

Brinton, Laurel J. (2002). The Structure of Modern English: A Linguistic Introduction. Philadelphia: John Benjamins

Clare Gilby. (2011). Teaching as a Foreign Language. Ormskirk: Edge Hill University

Fulcher, Glenn. (2010). Practical Language Testing. London: Hodder Education

James Jenkin. (2009). TEFL Uncovered, How to Teach Your Way Abroad with TEFL. Cambridge: British Council Learning

Jeremy Harmer. (1998) How to Teach English (1 ${ }^{\text {st }}$ ed). Edinburg: Pearson

Kim, Cholo. 2013. Vocabulary Acquistion With Affixation: Learning English Words Based on Prefixes \& Affixes. Second Language Studies. Vol. 31 No. 2

Lastari, Suharni, Sesmiyanti. (2015). An Analysis of Students' Ability in using Affix at the Third Year Students of English Department of STKIP PGRI West Sumatera in Academic Year 2015/2016. Graduate Thesis. STKIP PGRI West Sumatera

Michael McCarthy, Felicity O’Dell. (1994). English Vocabulary in Use - PreIntermediate \& Intermediate. Cambridge: University Press

Michelle Maxom. (2009). Teaching English as a Foreign Language for Dummies. Glasgow: Wiley

Mofareh Alqahtani. 2015. The Importance of Vocabulary in Language, Learning and How to be Taught. International Journal of Teaching and Education. Vol. 3 No. 3

Nurul Zuriah. (2009). Metodologi Penelitian Sosial dan Pendidikan ( ${ }^{\text {rd }}$ ed). Jakarta: Bumi Aksara

Richard Side, Guy Wellman. (1999). Grammar and Vocabulary for Cambridge Advanced and Proficiency ( $1^{\text {st }}$ ed). Edinburg: Pearson 
Roliah. (2014). An Analysis of Students' Mastery in Derivational Vocabulary at The First Semester at the Tenth Grade of SMAN 1 Sekampung Lampung Timur in Academic Year 2013/2014. Graduate Thesis. UIN Raden Intan Lampung

Spencer, Andrew. (1991). Morphological Theory ( $1^{\text {st }}$ ed). Oxford: Blackwell

Stuart Redman. (1997). English Vocabulary in Use - Pre-Intermediate \& Intermediate $\left(1^{\text {st }} \mathrm{ed}\right)$. Cambridge: University Press

Sudijono, Anas. (2011). Pengantar Statistik Pendidikan (1 ${ }^{\text {st }}$ ed). Jakarta: Rajawali Pers

------. (2011). Pengantar Evaluasi Pendidikan ( $1^{\text {st }}$ ed). Jakarta: Rajawali Pers

Sugiyono. (2008). Metode Penelitian Kuantitatif, Kualitatif dan $R \& D\left(5^{\text {th }}\right.$ ed). Bandung: Alfabeta

(2013). Metode Penelitian Kuantitatif, Kualitatif dan $R \& D$ ( $7^{\text {th }}$ ed). Bandung: Alfabeta

Suphat Sukamolson. Fundamentals of Quantitative Research. (On-line). Source in: www.culi.chula.ac.th/Research/e-journal/bod/Suphat Sukamolson.pdf Bangkok: Chulalongkorn University.

Súsanna Björg Vilhjálmsdóttir. (2015). The Dimensional Depth of Words: Vocabulary Knowledge and Reading Comprehension. Reyjavik: University of Iceland

Thomas, Alice. (1989). Common Prefixes, Suffixes and Roots. (On-line). Source in: www.cdl.org (the Center for Development \& Learning

Thornbury, Scott. (2002). How to Teach Vocabulary. Edinburg: Pearson

Tom Ritchey. 1996. Analysis and Synthetis. Systems Research, Vol. 8 No. 4

Yosuke Sasao. (2013). Diagnostic Tests of English Vocabulary Learning Proficiency: Guessing from Context and Knowledge of Word Parts. Graduate Thesis. Victoria University of Wellington 